\title{
EL MURCIANO JUAN LÓPEZ, PROCURADOR GENERAL DE TUNJA Y LÍDER DE LA REVUELTA NEOGRANADINA CONTRA LAS LEYES NUEVAS
}

\author{
POR \\ JUAN BTA. VILAR \\ Universidad de Murcia
}

\section{Planteamiento}

La proyección de Murcia y su región en la empresa americana de España es hasta el momento temática escasamente conocida, que por fortuna comienza a atraer la atención de estudiosos y especialistas. Aportación pionera en tan sugestivo campo de investigación es mi libro Los murcianos y América (1), donde creo probar suficientemente que la secular tesis, apriorística y nunca demostrada, de una pretendida marginalidad de Murcia y de sus gentes en la obra española en América, carece de todo fundamento. Antes al contrario, la monografía de referencia evidencia una sustantiva contribución murciana a los más variados campos de tan magno empeño, avalada por un soporte documental de primera mano, pero sobre todo su objetivo prioritario es abrir caminos (2), sugiriendo nuevos campos de investigación.

SIGLAS UTILIZADAS:

AGI: Archivo General de Indias (Sevilla).

AGS: Archivo General de Simancas.

AHN: Archivo Histórico Nacional (Madrid).

AHM: Archivo Histórico de la Región de Murcia.

AHP: Archivo Histórico de Protocolos Notariales (Murcia).

APm: Archivo Parroquial de Moratalla.

(1) J. B. Vilar, Los murcianos y América. Prólogo de M. Hernández SánchezBarba. Madrid. 1992.

(2) Véase J. B. VILAR, "Pasajeros murcianos a Indias en el siglo XVI. Problemas metodológicos e intento de cuantificación", Congreso de Historia del Descubrimiento, III (1992), págs. 57-78; VILAR, "Las emigraciones murcianas a Iberoamérica", en VV. AA., Historia General de la Emigración-Española a Iberoamérica. Madrid. 1992, II, págs. 371-408; VILAR, "Algunos funcionarios civiles, militares y 
Uno de ellos, y por cierto no el más insustantivo, es el de la aportación murciana al gran esfuerzo colectivo de la conquista indiana durante el siglo XVI. Contribución en modo alguno desdeñable a juzgar por los indicios disponibles, aunque secularmente oscurecida por una presencia proporcionalmente superior de Murcia y su reino en el Mediterráneo y en los compromisos europeos y norteafricanos de la Monarquía, destino marcado por una tradición histórica multisecular y por la propia geografía.

En estas páginas se intenta una aproximación al caso concreto de la intervención murciana en la fundación del Nuevo Reino de Granada y de la consolidación de esa conquista. Como hilo vector es seguida la andadura personal de Juan López, el bronco e inquieto serrano llegado de las ásperas fragosidades de la Murcia interior, en los confines con Granada, compañero en sus empresas de exploración y conquista del granadino Gonzalo Jiménez de Quesada, y luego fundador de ciudades, brillante gestor, líder de las revueltas de los pobladores neogranadinos en protesta por las Leyes Nuevas en defensa de los indios, y duro encomendero que encarna muy bien al conquistador español del XVI con sus virtudes y defectos.

\section{UNA VILLA MURCIANA EN LOS CONFINES CON GRANADA}

En el abrupto y recóndito noroeste murciano se encuentra Moratalla, uno de los extensos territorios comprendidos en los términos de Segura de la Sierra, concedidos con esta plaza por Fernando III de Castilla en 1242, concesión confirmada en el

eclesiásticos murcianos en América y Filipinas en el siglo XIX", Carthaginensia, VIII (1992), págs. 381-394; VILAR, "Un diplomático español entre Marruecos y Cuba. Nuevas aportaciones documentales a la biografía de Luciano López Ferrer y a sus conexiones con la Masonería", en Vilar (ed.), Murcia y América. VII Curso de Aproximación a la España contemporánea Murcia. 1992, págs. 23-55; VILAR, "Murcianos en el exilio republicano español de 1939 en América: su incidencia cultural sobre los países de destino", en Vilar (ed.), Murcia y América..., op. cit., págs. 57-76; VILAR, "América en la proyección exterior murciana", Carthaginensia, VII (1991), 79 págs. (separata). Existen otras contribuciones de investigadores diversos referentes a Murcia en sus relaciones con América, casi todas ellas encuadrables en el marco del V Centenario, siendo de destacar las incluidas en los ya mencionados n.os VII y VIII de Carthaginensia, el libro misceláneo Murcia y América ya mencionado; las contenidas en el $\mathrm{n}^{Q} 8$ de Anales de Historia contemporánea, Universidad de Murcia, monográfico sobre igual temática, así como diferentes monografías sobre la labor de los franciscanos murcianos en América realizadas por investigadores del Instituto Teológico de Murcia (Víctor Sánchez Gil, Pedro Riquelme Oliva, etc.), y las integrantes de la "Colección Carabelas" sobre literatura, arte, historia y ensayo publicadas bajo el patrocinio de la Comunidad de Murcia con ocasión del V Centenario. 
siguiente año por el infante don Alfonso -futuro Alfonso $\mathrm{X}$ el Sabio-, al maestre Pelayo Pérez Correa en recompensa por los importantes servicios prestados por la Orden de Santiago en la reconquista del reino musulmán de Murcia (3). En adelante Moratalla, segregada de Segura a mediados del siglo XIII —en 1256 era ya villa y cabeza de encomienda, siendo a la sazón su titular Fernán Pérez-, quedaría integrada en el compacto bloque de encomiendas santiaguistas, que en la raya murciana, servía de antemural a Castilla frente al sultanato granadino.

La historia de la localidad en los siguientes doscientos cincuenta años es fundamentalmente la de su castillo y la de una serie interminable de incursiones y reyertas fronterizas. Poblada inicialmente por unas pocas familias después de 1277, fallecido ya Pérez Correa, su funcionamiento real como villa se dejó esperar un siglo. Hacia 1350 - se desconoce la fecha precisa- los santiaguistas procedieron a hacer una formal repoblación, a la que sirvió de cobertura jurídica el fuero de Cuenca.

Es conocida con bastante precisión la dinámica demográfica de Moratalla en la transición del medievo a la modernidad (4). Tras la recesión que, por causas diversas, se da a mediados del siglo XV, se detecta una recuperación lenta pero sostenida. En 1468 la villa contaba con 180 vecinos, familias o fuegos -entre 800 y 1.000 habitantes-, que no pudiendo circunscribirse al recinto tradicional de la misma, tuvieron que desplazarse en parte a un arrabal inmediato "çercado a casa muro".

Tal expansión se acelerará a partir de 1488 al cesar definitivamente la amenaza granadina con la conquista por Fernando el Católico de Huéscar y todo el frente noreste del sultanato nasrí, y cuatro años más tarde con la expugnación final de Granada.

(3) Un excelente estudio sobre el marco geográfico de Moratalla se contiene en la sólida monografía de J. L. GONZÁLEZ ORTIZ, El Noroeste murciano. El hombre y sus tierras. Murcia. 1984. Para la evolución histórica del territorio a partir de la conquista cristiana resulta de consulta imprescindible la penetrante y documentada síntesis de A. MERINo Alvarez, Geografía histórica del territorio de la actual provincia de Murcia... Madrid. 1915, págs. 96-120, 290-319 y 439-453, ampliada por J. TORRES FONTES y colaboradores con aportaciones posteriores puntuales. Datos geográficos sobre la villa bajomedieval y su término en AHN, Códices, $\mathrm{n}^{2} 236 \mathrm{~B}$.

(4) M. RODRíguez Llopis, Documentos para la historia medieval de Moratalla. Murcia. 1988, págs. 26-27. El fenómeno estudiado, en el marco de las encomiendas santiaguistas murcianas en su conjunto, puede verse en la monografía del mismo autor: Señorios y feudalismo en el Reino de Murcia Los dominios de la Orden de Santiago entre 1440 y 1515. Murcia. 1984, págs. 31-107. Vid. a su vez RodRíguEz LLOPIS, Conflictos fronterizos y dependencia señorial: la encomienda santiaguista de Yeste y Taibilla (siglos XIII-XV). Albacete, 1982, págs. 13-114, y M. García, Carta de privilegios de 1440. Moratalla. 1988. 
De forma que en 1498 los vecinos eran ya 250, y 300 en 1507, no obstante la negativa incidencia de las múltiples epidemias, pérdidas de cosechas y crisis de subsistencias sufridas por Moratalla al filo del cambio del siglo.

En el año últimamente reseñado el vecindario intentaría por ello soslayarse a parte de sus obligaciones económicas respecto a los caballeros santiaguistas, invocando «...la estrema neçesydad que auian tenidon últimamente. Lo que no sería óbice para que en el mismo año de 1507 solicitaran licencia para construir un nuevo horno y otro molino. La presión demográfica resultó ser imparable en décadas posteriores. Quinientos vecinos hacia 1524 y 800 por los años de 1550 (5), efecto de una expansión agraria centrada en cultivos comerciales como la vid y el olivo, y en menor medida en los cereales tradicionales, la morera, el cáñamo y los frutales.

Si en principio la distribución de tierras comunales, próximas a la tradicional área de cultivo inmediata a la villa posibilitó a remolque del desarrollo demográfico, aquí como en otras partes (6), el acceso a la propiedad de no pocos campesinos pobres o con escasos recursos, iniciado el siglo XVI, por los años de 1510 , los mejores lotes habían sido ya asignados, o bien se hallaban acotados como dehesas, de forma que hubo de recurrirse a tierras más lejanas y cuya puesta en cultivo suponía inversiones de capital que solía sobrepasar las posibilidades del modesto labriego, de ahí que se beneficiaran de las mismas quienes poseían una cierta potencia económica. Comenzando por la familia Soto, emparentada con los poderosos Fajardo, adelantados del reino de Murcia, a quienes desde mediados del siglo XV habían sucedido en la titularidad de la encomienda. Por el contrario el pequeño cultivador, acosado por pertinaces sequías y calamidades, se veía obligado a transferir su propiedad a otros en situación de afrontar sus obligaciones fiscales y demás cargas, quedando

(5) La evolución demográfica de Moratalla en el contexto de la comarca murciana del Noroeste puede seguirse en F. CHACón JimÉnEZ y J. L. GonzÁleź ORTIZ, "Bases para el estudio del comportamiento demográfico de Cehegín, Caravaca y Moratalla en la larga duración (1468-1930)", Anales de la Universidad de Murcia (F. y Letras), XXVII, 1-2 (1978-1979), págs. 59-89. Para el entorno histórico véase J. B. VILAR, Cehegín, señorio santiaguista de los Borbón-Parma (1741-1856). Prólogo de J. Pérez Villanueva. Murcia. 1985; VILAR, "Las encomiendas santiaguistas de los Borbón-Parma. Aproximación al modelo de Caravaca-Cehegín (Murcia)", Hispania, XLV (1985); VILAR, "Una comunidad de franciscanos en la Murcia rural. El Colegio-Seminario de Misioneros de Cehegín (1690-1836)", Archivo Iberoamericano, XLIV, 176 (1984).

(6) M. ${ }^{a}$ T. Pérez Picazo, G. Lemeunier, El Proceso de modernización de la región de Murcia (siglos XVI-XIX). Murcia. 1984, págs. 58-93. 
como aparceros y arrendatarios, o bien reducidos a jornaleros obligados a abandonar el predio.

Un proceso éste remontable al siglo XIV pero acelerado en torno a 1500. Cierta descripción fechable hacia 1530 nos presenta el siguiente cuadro social de Moratalla: k...ay en la dicha villa quinientos y treynta y quatro vezinos pecheros, las dos partes dellos son gente rica y los demás jornaleros y de necessidad...» (7). Situación todavía relativamente halagüeña, pero que empeoraría drásticamente en años posteriores. Para colmo la absorción de un buen numero de moriscos granadinos desplazados de su país de origen por la conquista cristiana y luego por la represión que siguió al levantamiento alpujarreño (8), ennegrecería todavía más un panorama laboral ya de por sí sombrío.

El excedente demográfico se encaminará en primer lugar al piedemonte de la comarca montañosa, las feraces tierras de regadío situadas al sur, sobre todo los ejes del Segura y el Guadalentín, dominio del realengo, pero también más lejos. A Cartagena y su campo, al anexionado reino granadino, a Orán en la otra orilla del mar, e incluso a las Indias recién descubiertas. Fue éste un éxodo desorganizado pero masivo y sincrónico, donde se darían la mano el segundón de noble casa desprovisto de recursos, el clérigo desacomodado, y en particular el labrador despojado, el ganadero empobrecido, el menestral arruinado y el jornalero sin trabajo, dispuestos por igual a arriesgarlo todo en la búsqueda de la oportunidad que se les negaba en la tierra de origen.

\section{LOS LóPEZ, DE Moratalla}

El linaje López figura entre los de más rancia hidalguía y antiguo asentamiento en Moratalla. Su fundador el leonés Diego López es incluido por la tradición local en el número de los doce caballeros entre quienes el maestre Pelay Pérez Correa repartió los términos del lugar en el momento de la conquista, correspondiéndole una extensa heredad en la vega del Alárabe. En la siguiente centuria su directo descendiente Pero López de Villora sería el máximo protagonista en la jornada contra los musulma-

(7) AGS, Contadurias Generales, leg. 768, cfr. RodRíGuez LlopIS, Documentos..., pág. 50 .

(8) Actualizada información sobre la demografia morisca del Noroeste murciano en J. B. Vilar, Los moriscos del Reino de Murcia y Obispado de Orihuela. Prólogo de M. de Epalza. Murcia. 1992. 
nes granadinos conocida como batalla de los Carreños -1393-. Tres años más tarde el esforzado paladín aparecería muerto junto a un peñasco conocido desde entonces como Piedra de Pero López, según refiere la leyenda de la Piedra Encantada, recogida por A. Rubio Heredia (9).

Este cronista subraya que López y sus descendientes no levantaron su casa solariega en la villa, sino en el campo, en el paraje de Hoya de Alazor -en la actual diputación de La Rogativa-, situado en el centro de sus vastas posesiones, y cuyo sonoro nombre se incorporaron como segundo apellido. Sin embargo, como hace notar M. García (10), tal predio no comenzó a ser roturado hasta la caida de Huéscar en 1488, una vez que cesó la amenaza granadina.

A finales del siglo XV el caballero Pedro López de la Hoya de Alazor se destacó en las guerras de Granada y en la expugnación final de esta plaza con la hueste del conde de Tendilla. Su hijo Diego fue el último de su apellido a quien la versión tradicional atribuye residencia fija en la mansión campestre, dado que su primogénito Pedro, el heredero del mayorazgo, al fallecer su padre pasó a vivir en la villa, donde se hizo levantar una impresionante casona, que en parte todavía se conserva, inmediata a la actual iglesia parroquial.

Esa información, tradicionalmente aceptada, debe revisarse empero a la vista de la nueva documentación disponible, según la cual la importante heredad de referencia, a finales del siglo XV era pertenencia de cierto Sebastián Sánchez, cuya viuda Elvira Díaz, residente en Baza, en 1507 la vendió por medio de poder a Juan Polentano, vecino de Caravaca. Uno de los testigos de la transferencia ante notario fue Diego López, seguramente abuelo del que Rubio llamaría Magnífico Señor. Acaso la propiedad fuese con anterioridad de los López, quienes debieron rescatarla de Polentano con posterioridad a 1507.

Este Diego López, nacido en 1546 del matrimonio de su progenitor con doña María López del Puerto, estaba llamado a ser el más importante y emprendedor terrateniente de Moratalla, de la que fue regidor perpetuo y alcalde ordinario. $\mathrm{Su}$ paso por la alcaldía se haría memorable en los fastos de la villa por las mejoras urbanísticas que introdujo, la ampliación de la red viaria y construcción de diferentes puentes, la expansión del regadío, la

(9) Cosas de Moratalla (Provincia de Murcia). Ensayo histórico. Moratalla. 1915, págs. 137-159.

(10) Moratalla en los siglos XVI-XVII. Murcia. 1994. En prensa. 
roturación de tierras marginales y el fomento de una agricultura comercial basada en la vid y el olivo.

En tanto López, ya casado con doña Beatriz Guirao Carreño, se ocupaba en esos empeños, su hermano Juan abrazaba la carrera de las armas, distinguiéndose luego como capitán en la guerra de las Alpujarras, su otro hermano Alonso seguía estudios humanísticos para ordenarse probablemente de mayores, y su hermana menor, Maria, casaba con otro hidalgo, y rico hacendado, Juan Sánchez Cucharro, largos años alcaide de Moratalla. Diego, lo mismo que antes su padre don Pedro, fue en el XVI no sólo cabeza de su linaje - Hoya de Alazor - sino de los López en general, con vastas ramificaciones en la villa y sus términos.

Ya en 1480 se detectan (11) en Moratalla diferentes familias con este apellido. Aparte Pero López, hijo de Martín López, propietario de casas y tierras, y posiblemente el ya mencionado titular de Hoya de Alazor participante en la conquista de Granada, un Juan López "el Amo», rico propietario que además llevaba a censo tierras de la Orden; otro Juan López rel Capitán", y un Gonzalo López, un Martín López y un Diego López, todos los cuales gente principal.

En 1507, con ocasión de la siguiente estancia en la encomienda de los visitadores de la Orden (12), reaparece Pero López de Martín López, mencionado entre los dieciocho cuantiosos de la villa, y a su lado, también entre los cuantiosos, Juan López de Alonso López, Garçí López de Fuenllana, Diego López Miravete y Antón López, escribano público de Moratalla. Por detrás de estos cinco notables, quedaba una caterva de López, hundidos en el semianonimato del terrazgo y la menestralía.

Sobre los antecedentes familiares de nuestro Juan López, luego conquistador y poblador del Nuevo Reino de Granada, apenas se tienen datos precisos, dado que los libros parroquiales de Moratalla no se remontan más allá de 1545, año en que se abre el más antiguo, el $1^{10}$ de bautismos (13), sin que exista otra

(11) AHN, Órdenes Militares, Santiago, leg. 1065 C (Visita a la villa y encomienda de Moratalla por Fernando de Pineda y Juan Martínez). Véase también RODRíguez LlOPIS, Documentos..., págs. 57-77, 83-88.

(12) AHN, O. Militares, Santiago, leg. 1072 C (Visita ... id, por Diego de Córdoba y Alonso Martínez 1507). Véase a su vez RodRigUEz I.LOPIS, Documentos..., págs. 169-209.

(13) APm, Libr. $1^{9}$ de Bautismos (1545-1552). Las visitas santiaguistas a la encomienda en 1525 y 1536-37 nada aportan sobre López y su entorno familiar. Véase AHN, Ordenes Militares (Santiago), legs. $1080 \mathrm{C}$ (Visita de 1525), fs. 763784 , y 1082 C (Vis. de 1536-37), fs. 370.382 (Consultada copia microfilmada en AHM. Mircrofilms, rollo 3). 
documentación parroquial o concejil complementaria. En la fecha apuntada López, que se hallaba ausente en Indias, para donde debió embarcarse hacia 1528 -al siguiente año aparecerá avecindado en Santa Marta, ciudad de la costa de Tierra Firme-, debía contar cuarenta o cuarenta y cinco años, teniendo en torno a los veinticinco en el momento de embarcarse y habiendo nacido por tanto poco después de 1500 .

Juan llevaba el apellido de uno de sus abuelos, hecho por lo demás frecuente en la época. Consta por los libros de pasajeros a Indias (14) ser hijo de Gonzalo Sánchez y Elvira Rodríguez, con dos apellidos de amplia proyección local. De Gonzalo se sabe que era individuo con bienes de fortuna y además bastante conectado a las actividades concejiles. En la visita de octubre-noviembre de 1507 a la encomienda de Moratalla, realizada por los supervisores de la Orden, se le menciona como sujeto de arraigo en la villa, preocupado por el bienestar del vecindario y con la confianza del cabildo concejil. $\mathrm{kE}$ despues desto, [a] veynte a nueue dias del dicho mes de octubre del dicho año - reza el acta correspondiente-, ante los dichos señores vysitadores, paresció Gonzalo Sánchez, en nombre del conçejo de la villa de Moratalla e vezyno della, e presentó una petición en la cual pidió que la dicha villa tenía neçesydad de un otro molino e horno a cabsa de los vezynos e muncha poblaçión que ay en la dicha villa, [y] que lo mandase hazer el comendador Diego de Soto o les diesen liçençia al dicho conçejo para lo hazen.

Abierta la correspondiente información se vio, en efecto, que los molinos disponibles eran insuficientes, debiendo de guardar los vecinos turnos de diez y doce días para poder moler. Algo parecido sucedía con los hornos, siendo frecuente que las mujeres tuvieran que retornar a casa con la hogaza y sin poder cocer.

(14) C. Bermúdez Plata, Catálogos de Pasajeros a Indias durante los siglos XVI, XVII y XVIII, redactado por el personal facultativo del Archivo General de Indias bajo la dirección del director del mismo Don (...). Sevilla. 1946, vol. III. Los volúmenes posteriores, que cubren gran parte del $\mathrm{s}$. XVI, están a cargo de L. Romera Iruela y M. ${ }^{a}$ C. Galbís Díez. Interesan, a su vez, aportaciones complementarias a las anteriores. En particular: L. RUBIO MORENO, Pasajeros a Indias. Catálogo metodológico de las informaciones y licencias de los que alli pasaron, existentes en el Archivo General de Indias. Siglo 1' de la colonización de América. 14921592. Madrid. 1930-1931. A su vez las cuantificaciones ulteriores de que me ocupo por extenso en Los murcianos y América..., op. cit. Singularmente las realizadas por P. Boyd-Bowman, M. Mörner, J. Rodríguez Arzúa, J. Friede, J. L. Martínez, J. A. García-Abásolo y J. A. Calderón Quijano. Ultimamente, y referido al caso específico murciano, mis aportaciones de que se hace mención en nota $n^{Q}$ 2 supra, y las de J. Andreo Garcia y L. Provencio Garrigós tanto conjunta como separadamente. 
Por ello fue ordenado al comendador que hiciera molino y horno nuevos, y en su defecto, que se facultase al concejo para poderlo hacer. La gestión practicada por Sánchez dio por tanto los resultados apetecidos, de forma que su hijo, acreditado luego como hábil negociador en Indias, tenía a quien parecerse.

La niñez y mocedad de Juan López debió discurrir sin particulares altibajos como la de cualquier otro muchacho de su edad y condición. En el entorno familiar, en las calles del pueblo y en el campo en compañía de labradores y cabreros, en cuyas tareas les auxiliaba, bajo la mirada amable de la madre naturaleza. Mal que bien recibió sin embargo una educación que luego le permitiría asumir funciones como la procuraduría general de las ciudades federadas del Nuevo Reino de Granada, funciones éstas que en modo alguno hubieran estado a su alcance de ser un iletrado. Sin duda aprendió las primeras letras y algo de latinidad y humanidades en la escuela regentada en Moratalla por el clérigo caravaqueño Gines de Fuensalida, párroco de Santa María por los años de 1510, pintoresco personaje ingresado ya maduro en las filas de la Iglesia al salvar la vida prodigiosamente tras ser alanceado en los campos de Lorca, durante las contiendas granadinas (15).

Fuensalida, que cuando llegó a Moratalla tenía ya los cincuenta cumplidos, aparte de repasar latines a sus pupilos, debía calentarles la mollera relatando con todo lujo de detalles sus hazañas bélicas. El buen clérigo, fallecido a muy avanzada edad, vivió lo suficiente para ver emuladas y sobrepasadas sus aventuras por su discípulo Juan López allá en Tierra Firme y la Nueva Granada, en los nuevos mundos descubiertos para Castilla por Colón, al otro lado de la mar océana.

\section{Pasajero a Indias y vecino de Santa Marta. Participación DE LÓPEZ EN LAS CAMPAÑaS DE GARCÍA DE LERMa}

Se desconoce el momento y circunstancias en que Juan López se embarcó para Indias. En los libros de pasajeros no consta el asiento correspondiente a este primer viaje, sin duda porque, como tantos otros, pasó a Ultramar de forma clandestina, impactado por las fantásticas noticias circuladas sobre los nuevos países conquistados por Cortés y sus lugartenientes.

(15) J. B. VILAR, El indiano Juan López. Prólogo de A. Garcia-Abásolo. Murcia. 1993, págs. 43-47. 
López, que llegaba tarde a la conquista novohispana, prefirió encaminarse a Panamá y a la cornisa caribeña de Tierra Firme, puerta de entrada del inmenso subcontinente meridional, todavía inexplorado, del que se sabía que albergaba imperios fabulosos que en nada desmerecian del azteca, y que no tardarian en ser sojuzgados.

El murciano debió llegar a Santa Marta, primera ciudad europea en la actual Colombia, entrado el año 1528. Lo hizo poco antes que el nuevo gobernador, el banquero burgalés García de Lerma, y por las mismas fechas que el capitán Pedro de Heredia, un madrileño llamado de La Española para desempeñar el oficio de teniente de gobernador de Pedro de Vadillo, enviado por el rey para asumir esa gobernación tras la muerte de Rodrigo de Bastidas, fundador de Santa Marta y descubridor del gran puerto natural que llamó Cartagena de Indias por recordarle la Cartagena española, y en donde andando el tiempo Heredia levantaría la ciudad del mismo nombre en 1533.

La primera noticia sobre López en Indias aparece datada en septiembre de 1529. Se trata de cierto testimonio (16) de Juan Pérez, escribano público de Santa Marta, en Tierra Firme, donde se hace mención de "Juan López, soldadow, entre los vecinos y pobladores de la expresada ciudad, herido en «la conquista y pacificación del Pueblo Grandew, dura y cruenta jornada en la que resultó también gravemente herido el nuevo gobernador y capitán general García de Lerma (17). La campaña reportó más gloria que beneficio, por lo que el propio gobernador dispuso que del cuantioso botín recogido poco después en la productiva entrada al valle de Buritaca, fuera asignada una ayuda a quienes "vinieron heridos del Pueblo Grande y a otra gente necesitada».

Centenar y medio de individuos se beneficiaron de esas gratificaciones, distribuidas según los merecimientos y rango de cada cual, en partidas individuales fluctuantes entre los «15 pesos de buen oro" asignados al capitán Berrio y los 20 señalados al valenciano Miguel Carlos "para pagar la costa de artillería", a un peso consignado a Gonzalo Pizarro y otro a Francisco de Cisneros

(16) "Acta sobre los componentes y reparto de botín en la entrada al valle de Buritaca y Pueblo Grande (septiembre, 1529)", cfr. J. FRIEDE, Documentos inéditos para la Historia de Colombia, Bogotá. 1955, II, págs. 74-84.

(17) Vid. descripción de la jornada por García de Lerma, cfr. FrIEDE, Documentos..., II, págs. 115-118. Más sobre los pobladores de Santa Marta y aledaños en M. GónGORA, Los grupos de conquistadores en Tierra Firme (1509-1530). Fisonomia histórico-social de un tipo de conquista. Santiago. 1962. Véase también E. MARTín ACOSTA, "García de Lerma en la inicial penetración del capitalismo mercantil en América, Congreso de Historia del Descubrimiento, II (1992), págs. 429. 455. 
y otros dos compañeros «por pasar los tiros desde la playa a la plazaw. López fue agraciado con ocho pesos de oro, suma importante tratándose de un simple soldado, lo que indica que sus merecimientos debian ser harto estimables.

Era aquel un país ubérrimo y exuberante, de agradable clima en la costa y ricas pesquerías de perlas, pero de selvas impenetrables, pantanos y ríos impracticables infestados de caimanes e indios hostiles. Los del litoral de Santa Marta y Cartagena tenían fama de ser los más fieros e indómitos de cuantos hasta el momento encontraron los españoles en el Nuevo Mundo. Gonzalo Fernández de Oviedo (18), que había fracasado en un intento de someterles, despechado dice de ellos ser antropófagos, homosexuales, irreductibles y certeros tiradores con sus flechas envenenadas: "...comen carne humana y son abominables sodomitas y crueles, y tiran [tan bien] sus flechas emponzoñadas de tal yerua q. por marauilla escapa hombre de los q. hieren, antes mueren rauiando, comiéndosse a pedaços y mordiendo la tierra...».

Martín Fernández de Enciso (19), por el contrario, justifica su talante fiero y desconfiado por causa de los reiterados ataques y depredaciones sufridos a manos de los europeos, presentándoles como gente aguerrida y duros en la lucha, tanto los hombres como las mujeres: "Son bellicosos y usan arcos y flechas. Tiran todos las flechas con yerua de la malas.

Tales fueron las poblaciones autóctonas con las que tuvieron que vérselas los habitantes de Santa Marta. De la dureza de éstos, por su parte, da fe el hecho de que su conducta fuera sistemáticamente denunciada por los misioneros. De ello se haría eco el propio obispo local, acosada su diócesis por la miseria ante la indiferencia de unos pobladores atentos sólo a su lucro personal. En 30 de mayo de 1540 remitiría al monarca un informe espeluznante, en el que, entre otras cosas, se lee: «En estas partes no hay cristianos, sino demonios; ni hay servidores de Dios y del rey, sino traidores a su ley y al rey....".

Que Juan López se identificaba plenamente con las opiniones e intereses de los otros pobladores de Santa Marta, lo prueba su demanda dirigida en enero de 1536 al Consejo de Indias, con otros conquistadores. Pretendían que fuesen autorizado reducir

(18) G. FERnÁNDEZ DE OVIEDo, Historia General y natural de las Indias. Edición y est. preliminar de J. Pérez de Tudela Bueso. Madrid. 1959, II.

(19) M. FERNÁNDEZ DE ENCISO, Suma de Geografía q./trata de todas las partidas y provincias del mundo; en especial de las Indias. $Y$ trata largamente del arte de marear; juntamente con la espera en romance:/ con el regimiento del sol y del norte; nue/uamente hecha. Sevilla. 1519, s.f. 
a esclavitud a cuantos indios de guerra fueran capturados con las armas en la mano, así como a sus mujeres e hijos (20).

4. ENTRADA Y DESCUBRIMIENTO CON JIMÉNEZ DE QUESADA DE LA REGIÓN DEL RÍo GRANDE DE LA MAGDALENA. LA SIERRA Y VALLE DE MURCIA

Desde los años de 1535 la actividad colonizadora en el dilatado territorio comprendido entre Santa Marta y Darién, en el Atlántico, y en el transpaís de la cornisa panameña al Mar del Sur, es ciertamente intensa, jalonada con la ocupación de nuevas regiones y la fundación de ciudades. Esa euforia expansionista se vería incentivada por la espectacular conquista por Francisco Pizarro y sus colaboradores del vasto imperio incaico, empleando en la empresa efectivos y recursos más que modestos para la magnitud de los logros alcanzados. Precisamente en el 35 con la fundación de Ciudad de los Reyes (Lima) podía darse por concluida la conquista, abriéndose la fase de colonización.

El papel de Cartagena de Indias como plataforma de descubrimientos es subrayada por el propio Quesada (21) en atención a las excepcionales condiciones reunidas por ese puerto y su proximidad al río Magdalena, principal ruta de penetración en un país rico y de excelente clima, ruta seguida por él en su expedición de conquista del imperio de los chibchas (1536-1538), el tercero del Nuevo Mundo por su importancia, en cuyo centro fundaría Tunja y Santa Fe, en la región de Bogotá, llamando aquellas regiones Nuevo Reino de Granada. Individuos oriundos de tierras murcianas como Hernando de la Santa, Francisco Gutiérrez de Murcia y Francisco de Murcia -éste uno de los conquistadores de Vélez-, que llegaron en fecha indeterminada -en ocasiones soldados de Federman y Belalcázar captados como pobladores- contribuyeron señaladamente a la viabilidad de la nueva circunscripción. También Martín Pujol y Juan López - ambos de Moratalla-, cofundadores de Bogotá y de Tunja, y encomenderos en esas regiones. López marcharía luego a su patria de origen en busca de colonos, colaborando en ésto con el

(20) VILAR, El indiano..., pág. 49.

(21) G. Ximénez de Quesada, "El manuscrito de la conquista del Nuevo Reino de Granada", en D. Ramos PÉREz, Ximénez de Quesada en su relación con los cronistas y el Epítome de la conquista del Nuevo Reino de Granada. Sevilla. 1972, págs. 279-307. Véase también J. RodrígUez FreYle, Conquista y descubrimiento del Nuevo Reino de Granada. Edición de J. Delgado. Madrid. 1986. 
lugarteniente de Quesada, Juan de Junco, celebrado como «soldado [de las guerras] de Italia [y] persona de gran valor [que] trajo soldados a su costan.

En Santa Marta, abril de 1536, el licenciado Gonzalo Jiménez de Quesada se dispone a emprender su entrada en la región del Río Grande de la Magdalena, por largo tiempo considerado éste erróneamente vía natural para llegar por tierra al Perú, y punto de partida para el sometimiento de las amplias e ignotas regiones del interior, llevando entre sus acompañantes a los esforzados y veteranos soldados Juan López y Martín Pujol. Eran en total 700 hombres de a pie, repartidos en ocho compañías, y 200 de a caballo. Unos bergantines de apoyo remontaron el río Salicron en 26 de abril de 1536, y la campaña fue pródiga en dificultades y penalidades, sobre todo hasta Latora, «...donde -refiere Alonso de Santa Cruz en su crónica- determinaron de invernar por ser el tiempo de muchas aguas y no poderse caminar por tierran, y luego en el siguiente tramo, también de selvas y ciénagas, hasta alcanzar la meseta bogotana

El capitán granadino, en funciones de teniente de gobernador de las tierras que conquistase, e investido de plenos poderes, llevaba instrucciones precisas (22) del adelantado y capitán general de Santa Marta, don Pedro Fernández de Lugo, para que practicara con los indios una política de pacífica atracción. Logrado ese objetivo, «...les pidáis oro, aquello que pueden dar según la calidad y cantidad de los pueblos, diciéndoles cuanta necesidad hay y tengo para la paga de los navíos como para la comida de los cristianos y lo que más os parecierem. Ahora bien, «....al pedir el oro no se les haga vejación y molestias ni otros malos tratamientos, sino en tal manera se lo pidáis que, después de darlo, queden alegres y contentos para de allí adelante estar de paz y con propósito y voluntad de tornar a dar [más] oro...... A quienes no entraren en razones «...les haced la guerra a fuego y a sangre o como os pareciere".

Lugo no olvidaba señalar las normas que debían observarse en el reparto del botín entre los expedicionarios, debiendo apartarse puntualmente el quinto correspondiente a la Corona y la parte que le pertenecía a él en su condición de gobernador general. Todo lo cual debería consignarse con exactitud en un libro de cuentas abierto a tal fin, debiendo constar con detalle el

(22) Instrucción del adelantado don Pedro Fernández de Lugo a Gonzalo Jiménez de Quesada sobre la entrada en la región del Río Grande o Magdalena, Santa Marta 4 abril 1536, cfr. FRIEDE, Documentos..., IV, págs. 75-79. 
peso y calidad tanto del oro como de las joyas recibidas o incautadas. Por último, preceptuaba que caso de fallecer Quesada, asumiría el mando su segundo Juan de Junco, y en lugar de éste, en su caso, el capitán Gonzalo Suárez.

El libro de referencia (23), en mayor medida que cualquier otra fuente, es de máximo interés por cuanto evidencia una irrecusable intervención murciana en la empresa. Entre mayo de 1536 y octubre del siguiente año Jiménez de Quesada recaudó 204.970 pesos en oro de diversas calidades, aparte una importante cantidad de esmeraldas cuyo valor no es precisado. Con posterioridad a esa fecha, entraron varias partidas menores de diversa procedencia. Uno de los parajes visitados fue bautizado como valle y sierra de Murcia, cuyos naturales aportaron en señal de acatamiento oro fino por valor de 330 pesos y oro bajo valorado en otros 180, en total 510 pesos, aparte «...quince piedras esmeraldas, entre chicas y grandes, de todas suertes".

La clave de la atribución de tan sonoros topónimos murcianos a una comarca visitada en esta ocasión por vez primera, viene dada por la participación en la empresa de gentes murcianas. Muy probablemente presentaba tal origen cierto Andrés de Murcia, miembro destacado de la expedición, que en 9 de marzo del 37 manifestó un botín personal de kdoscientos once pesos de oro fino». No debía ser el único con esa procedencia. La fuente no menciona a Juan López, aunque sin duda estuvo presente, dado que sus servicios en esta ocasión fueron recompensados al término de la campaña, amén de que el libro-registro sólo alude a una parte de los expedicionarios. Entre estos, cierto Martín Pujol amigo y coterráneo de López a quien me refiero por extenso en otro lugar, declarante de ocho pesos de oro fino. Pujol fallecería en Santa Fe de Bogotá en 1563. En 20 de enero del siguiente año, Inés López, su hija y heredera, en nombre propio y de su marido Ginés Rodríguez, vecinos de Moratalla, facultó a un sobrino suyo para cobrar la herencia.

Pujol, según veremos luego, daría mucho que hablar como encomendero en el naciente Nuevo Reino de Granada, como también el capitán Murcia ya mencionado, sobre quien constan diferentes referencias en los protocolos de que se hizo cargo Alonso Téllez al asumir las funciones de escribano público en Santa Fe de Bogotá en 1544, entre las cuales unas obligaciones ejecutadas contra el expresado Murcia, un pleito de cierto Gregorio López con Murcia sobre una india, y otro contra él por

(23) Cfr. FrIEDE, Ibidem, IV, págs. 80-89. 
parte del capitán Juan de Céspedes. Después del 44 sabemos que Murcia fijó su residencia en Vélez, ciudad neogranadina de que debió ser uno de los fundadores, donde prosiguió sus disputas y pleitos con otros vecinos sobre la posesión de tierras y el control de indios encomendados.

El más rico botín de tan fructífera entrada lo dio el valle de Tunja, objetivo prioritario de Quesada junto a la comarca de Bogotá. En el mismo fue obtenida una importante cantidad de oro valorada en 150.500 pesos, aparte «doscientas ochenta piedras de esmeraldas, chicas y grandes y de todas suertes». En el botín participó López, que por otras fuentes consta ser uno de los conquistadores y pobladores de la nueva villa.

En cuanto al valle de Sachica, tomado al cacique del lugar, conocido por Comeriqui, reportó a su vez botín en modo alguno despreciable. Setecientos ochenta pesos en oro fino más otros 450 en oro bajo, por tanto 1.230 pesos, "mas veinticuatro piedras de esmeraldas, chicas y grandes, de todas suertes" (24), riquezas que en parte estimable fueron a parar, a su vez, al bolsillo del murciano, destacado en la jornada, circunstancia que le valdría ser heredado en el lugar, que terminaría por controlar enteramente en calidad de encomendero (25).

\section{EXPLORADORES Y CONQUISTADORES. LÓPEZ, FUNDADOR Y VECINO DE TUNJA}

La lejana región de Tunja flanquea por el noroeste el altiplano bogotano, siendo tierra brava y pintoresca, sembrada de lagos, bosques, mesetas cubiertas de pastos, fértiles llanuras junto a los ríos y minas de oro y esmeraldas en las agrestes montañas. Se accedía hasta allí por el Río Grande de la Magdalena, entre los mil peligros de su largo y accidentado recorrido, y que ya en la desembocadura aparecía infestado de caimanes y otras temibles bestias: «...muchos y muy fieros lagartos —anotaría el cronista

(24) Ibidem, IV, pág. 89. Véase también FrIEDE, “Antecedentes históricogeográficos del descubrimiento de la meseta chibcha por el Lcdo. Gonzalo Jiménez de Quesada", Revista de Indias, X, $n^{\circ} 40$ (1950), págs. 327-348; FRIEDE, "Las ideas geográficas en la conquista del Nuevo Reino de Granada", Revista de indias, XV, $\mathrm{n}^{2}$ 62; M. Lucena Salmoral, "Epítome de la conquista del Nuevo Reino de Granada", Ximénez de Quesada, 13 (1962), págs. 33-60; D. Ramos PÉrEz, Ximénez de Quesada, cronista Sevilla. 1972.

(25) Juan López, "encomendero de Sachica, en Tunja", sería celebrado luego por los historiadores de la conquista, como uno de los fundadores del Nuevo Reino de Granada. Véase Rodriguez FREYLE, conquista..., pág. 94. 
Cieza (26) - y otros grandes pescados y manatíes, que son tan grandes como una becerra y casi de su talle.... Aunque el mar quedaba más cerca del lado del golfo de Maracaibo, por el momento ese camino por collados y ásperas veredas resultaba impracticable.

Tunja era El Dorado de los inmensos páramos situados al sur de la cornisa caribeña, según referirá el milanés G. Benzoni (27) que visitó la región en 1545. El país de Tunja era dominado por el cacique del mismo nombre, sempiterno rival del de Bogotá y en permanente guerra con él. De hecho uno y otro daban sus nombres a las respectivas regiones, tenían sujetos por la fuerza de las armas a los pueblos circunvecinos y conformaban en cierta medida un imperio compartido, el chibcha, fundado en la agricultura y la metalurgia, y de cultura bastante evolucionada.

Jiménez de Quesada no dejó de sacar partido de los enfrentamientos de ambos jefes para somerterles por separado. Recorridas las comarcas bogotanas en una primera incursión, marchó sobre Tunja, «...que tenía y poseía muy gran cantidad de oro él y sus indios.... (28). Habiendo hecho el camino a marchas forzadas y en pocas jornadas, utilizando apenas la mitad del tiempo usual en ese recorrido por no entretenerse a escaramuzar con los tropeles de indios que le salían al paso, sorprendió a Tunja en su poblado y le impuso una paz y alianza que conllevó la entrega de importantes cantidades de objetos de oro aderezados con esmeraldas y otras piedras preciosas atesorados en el lugar.

Jiménez marchó desde este punto con una parte de su gente a un paraje situado a varias jornadas, asiento de un reputado santuario cuyo jefe y gran sacerdote era cierto Sogamoso, tan pronto supieron que las riquezas de Tunja palidecían al lado de los tesoros allí acumulados. Esta vez no cogieron desprevenido al cacique, que pudo retirarse a tiempo con sus más preciadas pertenencias. Con todo, "...todavía los soldados hallaron algún oro sobre algunas sepulturas de muertos y en el suelo de algunos

(26) P. Cieza DE León, La Chronica / del Perú / nueua/mente escrita por (...), vecino de Se/uilla. En Anvers. MDLIII, cap. XXXI. 1989.

(27) G. Benzoni, Historia del Nuevo Mundo. Ed. de M. Carrera Díaz. Madrid.

(28) Fray P. DE Aguado, Primera Parte / de la / recopilación historial resolutoria de Santa Marta y Nuevo Reino de Granada de las Indias del Mar Océano. En el qual se trata / del primer descubrimiento de Sancta Marta y Nuevo Reino, y / lo en él subcedido hasta el año / de sensenta y ocho, con las guerras y funda/ciones de todas las cibdades y villas de él. / Hecho y acabado por el Reverendo Padre (...), de la Órden de Sanct Francisco (...). Dirigido a la S.C.R.M. del Rey Don Felipe nuestro señor, segundo deste nombre, 1.a ed. Madrid, 1930, I, pág. 201. 
templos, de lo que por no mirar en ello habían dejado; y destos rezagados mendrugos se juntaron en este pueblo cuasi seiscientas libras de oro" (29).

El relato de fray Pedro de Aguado nos introduce en el tema de la profanación, saqueo y destrucción sistemáticos de templos y tumbas prehispánicas en esta y otras regiones, por una doble motivación religiosa y crematística, y que en el Nuevo Reino de Granada fue sin duda una de las actividades más lucrativas entre europeos, hasta el punto de tener que ser reglamentada por el propio Consejo de Indias, como puede constatarse en el corpus documental publicado por J. Friede. El hecho no escapó desde luego a los cronistas de la contienda y a quienes, posteriormente (30), se han ocupado de la historia neogranadina del XVI.

Llegados de Santa Marta los esperados refuerzos, Jiménez prosiguió sus incursiones y correrías por el país, en cuyo centro, la meseta de Bogotá, convergería en memorable ocasión, a la que asistió Juan López, con los también insignes exploradores y conquistadores Nicolás Federman y Sebastián de Belalcázar, procedentes respectivamente de la costa de Venezuela y del no menos lejano reino de Quito. Para asegurar el país, al que el granadino llamó Nuevo Reino de Granada en recuerdo de su patria de origen, fundó tres ciudades, Santa Fe, Málaga y Vélez, en recuerdo de otras tantas de su tierra. Las dos últimas por los capitanes Gonzalo Suárez Rendón y Juan Galeano. Pero los nombres que perduraron en Santa Fe y Málaga fueron los de Bogotá y Tunja, sus denominaciones prehispánicas. La última era conocida también como Chipata, por hallarse situada en el territorio de ese nombre, país del Zaque.

Juan López figura como testigo en el poder (31) dado por Gonzalo Jiménez de Quesada, lugarteniente general del Nuevo Reino de Granada y provincia de Santa Marta, a su hermano el capitán Fernán Pérez de Quesada, alguacil mayor del mismo, como representante suyo con autoridad plena durante su ausencia en España, a donde marchaba "a dar cuenta a Su Magestad» sobre su conquista y actuación, y a reclamar las correspondientes recompensas, que incluyeron el nombramiento de mariscal y diferentes bienes y rentas. El documento extendido por el escri-

(29) Ibidem, I, pág. 214.

(30) M. Jiménez DE la Espada, "Prólogo" a P. Cieza de León, La guerra de Quito. Madrid. 1877, vol. II.

(31) FrIEdE, Documentos..., V, págs. 159-162. 
bano Rodrigo de Villareal, aparece fechado en Santa Fe en 8 de mayo de 1539, firmando como testigos, además de López, significativamente Martín Pujol y el cordobćs Juan Tafur, prueba de que en mayo del 39 López se encontraba en Bogotá, que no en Tunja, y que era persona próxima y de la confianza del conquistador granadino, igual que Tafur y Pujol —éste también murciano y de Moratalla como queda dicho-, figurando los tres entre sus colaboradores y capitanes más incondicionales, allegados, y en consecuencia, inseparables del general. Ello sin perjuicio de tener los tres vecindad en Tunja, donde habían sido heredados y donde se hallaban por tanto sus tierras, intereses y hacienda.

Por tanto la presencia de López en Santa Fe de Bogotá era circunstancial, dependiendo de la de Quesada, que hasta entonces apenas se había dado un momento de reposo, afanado en la organización del recién adquirido reino. Por ello en las sucesivas actas de acatamiento por el cabildo santafecino del hermano del conquistador como teniente de capitán general en funciones (32), en que se hace mención de los dos alcaldes, siete regidores y otros dignatarios concejiles, amén de diferentes vecinos que firman como testigos, el murciano no es mencionado, pues obviamente no tenia vecindad en esa ciudad. Para entonces ni siquiera residencia, dado que tan pronto se ausentó Jiménez, el de Moratalla volvió grupas con sus criados y servidores en dirección a Tunja, llegando a tiempo para estar presente en la formal fundación de la urbe, en el antiguo emplazamiento de un poblado de indios quimizas al pie de la Loma de Ahorcados, por Gonzalo Suárez Rendón en 6 de agosto de 1539. Digo formal porque sobre el papel existía desde el año anterior siendo la primera localidad europea en el actual interior colombiano y con categoría de ciudad desde 1541. El paraje era frío -2.850 metros de altitud-, pero de emplazamiento estratégico por controlar la sierra minera y la entrada al valle de Sogamoso.

Aunque incluido López en la distribución de solares y tierras que el flamante cabildo encomendó a Alonso de Paniagua, no lo fue desde luego en la medida de sus merecimientos, por haberse revisado y mermado en su caso como en el de otros conquista-

(32) Ibidem, V, págs. 162-165. Sobre la fundación y andadura inicial de la nueva ciudad, véase N. Garcín SAMUdio, "Fundación de la ciudad de Tunja", Boletín de Historia y Antigüedades, XXVII, 298 (1939); U. RoJAS, Escudos de armas $e$ inscripciones antiguas en la ciudad de Tunja. Bogotá. 1939; S. RUBIO OzIAS y M. BRICEÑo, Tunja desde su fundación a la época presente (s.l.) 1909; R. DE RIVAS; Los fundadores de Bogotá. 2. ed. Bogotá. 1938; M. GERMÁN ROMERO, Joan de Castella. nos, un examen de su vida y de su obra. Bogotá. 1964. 
dores concesiones previas obtenidas del ausente fundador del reino. En tal sentido operaron los ediles, siguiendo dócilmente las instrucciones del teniente de gobernador en funciones, atento como sus sucesores a su propio enriquecimiento y a favorecer a sus incondicionales, aprovechando la circunstancia de haber sido facultado por su hermano para hacer y deshacer según su voluntad y recto entender.

Que López y otros veteranos conquistadores no fueran bienquistos de Pérez de Quesada se evidencia en el comportamiento de éste, no sólo recortándoles las dádivas ganadas en el campo de batalla, so pretexto de que habían sido prodigadas de forma apresurada y un tanto irreflexiva, lo que en parte era cierto, sino también excluyéndoles del naciente cabildo por él mediatizado. En efecto, el nombre de López y otros reputados capitanes con vecindad en Tunja no figura entre los agraciados con regidurias y otros oficios, siéndolo por el contrario individuos de su confianza. Veteranos unos como el ya mencionado capitán Suárez Rendón, su representante en el distrito, o el también capitán Juan de Junco, o bien de ulterior llegada otros como Andrés Poyatos y Pedro de Colmenares, este último hasta el momento con vecindad e igual cargo en Santa Fe.

La actuación de Pérez al frente del gobierno neogranadino dejaba bastante que desear. Los abusos de los conquistadores y encomenderos de primera hora, que afirmaba pretender atajar, no tardaron en palidecer ante sus propias tropelías. Aparte de haber defraudado al fisco importantes sumas y cometidas no pocas arbitrariedades con los pobladores españoles, de todo lo cual habría de dar después cumplida cuenta en la residencia que se le hizo en 1543, dio muestras de brutalidad pocas veces vista respecto a las poblaciones aborígenes, y muy singularmente con el cacique Sogamoso y su pueblo, que controlaba las más productivas minas de Tunja.

Cuando éstas y otras denuncias (33) llegaron a España levantaron lógica indignación en los organismos responsables de los asuntos indianos. Una Real cédula del príncipe Felipe, fechada en Valladolid a 13 de febrero de 1544 (34) dispuso que el licenciado Miguel Díez de Armendáriz, a la sazón en Cartagena de

(33) "Diligencias practicadas sobre la actuación de Hernán Pérez de Quesada en el Nuevo Reino de Granada (Tunja, 28 septiembre 1543)", cfr. FRIEDE, Documentos..., VII, págs. 86-87. En cuanto a J. de Junco y los pobladores que llevó consigo a Cartagena y la Nueva Granada, véase AGI, Audiencia de Santa Fe, leg. 987, lib. 1, fs. $88 v-89 v$.

(34) Cfr. Friede, Documentos..., VII, págs. 185-186. 
Indias, procediera de inmediato a hacer información minuciosa, e incoar los correspondientes procesos, no sólo a Pérez de Quesada, sino a cuantos españoles habían tenido o tenían indios encomendados, o de alguna forma habían intervenido en la conquista neogranadina, al objeto de establecer posibles responsabilidades criminales.

De la investigación practicada se siguió probarse numerosos delitos y por tanto fueron sometidos a residencia, proceso y sentenciados a diferentes penas, tanto Hernán Pérez como un elevado número de dignatarios, o que lo habían sido con anterioridad, incluido el cabildo concejil de Santa Fe en pleno, lo que indica hasta qué punto estaban generalizadas prácticas punibles en el trato con los indios. Claro está que los españoles no se andaban con más miramientos entre ellos. Cuando en 1546 Domingo de Aguirre, regidor de Tunja desde el año anterior, se ausentó de la ciudad sin permiso del gobernador Alonso Fernández de Lugo, éste ordenó como castigo ejemplar que le cortasen un pie.

A su vez, el pesquisidor Díez tampoco anduvo remiso en la investigación de los patrimonios neogranadinos, descubriendo múltiples irregularidades, y procediendo a las correspondientes confiscaciones. Entre los investigados, como después se verá, no podría dejar de figurar el encomendero Juan López.

Entre tanto la ciudad de Tunja prosperaba y crecía rápidamente. Desde la fundación misma el vecindario asumió como responsabilidad colectiva la creación de las condiciones necesarias llamadas a asegurar un rápido desarrollo de la urbe y su florecimento ulterior. En tal dirección se encaminarían los acuerdos adoptados en cabildo abierto celebrado en agosto de 1539, de que levantó acta (35) el escribano Diego de Segura.

Como previsión inicial fue solicitado de la Corona la edificación de una iglesia mayor y algún otro lugar de culto, y su conveniente dotación y equipamiento, así como la asignación a ambos templos de «...religiosos, hombres expertos de ciencia y conciencia para la conversión de estos infieles, para que los instruyan en la Fe Católica, pues ésto es lo principal que se ha de buscary. Todo ello con cargo a la Real Hacienda al carecer por el momento de propios la ciudad. Los señalados por Quesada en el momento de la conquista todavía no habían sido confirmados por el rey.

(35) Peticiones presentadas al Consejo de Indias por la ciudad de Tunja, en el Nuev Reino de Granada (1539), cfr. FRIEDE, Documentos..., V, págs. 172.174. 
Por ello los de Tunja demandarían del Consejo de Indias que no fuesen variados los dilatados términos que fueran concedidos por aquel antes de su marcha, pues al ser el granadino el mejor conocedor del país, era quien más autorizadamente podía prever las necesidades futuras de la naciente urbe. Por tanto deberían ser confirmados los propios y rentas que el concejo tenía previsto para su holgado mantenimiento, y que el capitán general de Santa Marta, en cuyo nombre había actuado como lugarteniente el conquistador del país, cuando viniera a hacer el reparto de tierras y aldeas entre los pobladores, las diera k...a los moradores y conquistadores, pues lo han trabajado y ganado con tanto trabajo de sus personas y hacienda, mandando especialmente al dicho gobernador que no de repartimiento ninguno a los que nuevamente llevare consigo, hasta que haya repartido y cumplido con los conquistadores".

Un memorial (36) paralelo remitido al Consejo por Santa Fe de Bogotá, la otra ciudad fundada por Quesada en las altiplanicies, y que terminaría convirtiéndose en cabeza del nuevo país, documento más extenso y detallado que el enviado por Tunja, amplía nuestro conocimiento sobre los problemas y aspiraciones de ambas nacientes localidades.

\section{LÓPEZ, PROCURADOR GENERAL DE TUNJA Y LÍDER DEL MOVIMIENTO NEOGRANADINO EN FAVOR DE LA REDISTRIBUCIÓN DE TIERRAS Y ENCOMIENDAS}

Entre mediados de 1539 y noviembre del 43, en que volvemos a saber del murciano, éste dedicó su tiempo a la atención de sus tierras y asuntos personales. Compartía con los otros conquistadores y pobladores de la primera hora el malestar generalizado entre ellos por la postergación y atropellos de que se sentían objeto por parte de los sucesivos gobernadores, más atentos a acrecentar sus patrimonios y los de sus colaboradores y protegidos que a mirar por el bien público.

El detonante de la protesta, aquí como en otras partes, fue sin embargo la promulgación de las Leyes Nuevas en Valladolid, en 4 de junio de 1542, llamadas a atajar los generalizados abusos introducidos en Indias, sistemáticamente denunciados por los eclesiásticos, y de que los indios eran las principales víctimas, al

(36) Peticiones presentadas al Consejo de Indias por la ciudad de Santa Fe (1539), cfr. FRIEDE, Documentos..., V, págs. 165-172. 
tiempo que intentaban introducir y vertebrar una administración mejor articulada y sobre todo más justa para las poblaciones autóctonas. Ni qué decir tiene que las Leyes Nuevas suscitaron unánime repulsa entre los pobladores europeos, perjudicados en sus intereses, y sobre todo entre aquellos que habían hecho la conquista y que sumaban a éste otros agravios, siendo por tanto ellos quienes principalmente impulsaron y extendieron el movimiento de protesta.

Pretendían la suspensión total o parcial de las denostadas Leyes Nuevas, cuya aplicación conllevaba la abolición del principio hereditario en la transmisión de las encomiendas, así como el secuestro y expropiación de tierras y bienes usurpados a los indios y a la propia Corona. Reclamaban a su vez la revisión general de los repartos hechos hasta el momento, al objeto de favorecer y heredar mejor a los pobladores que hicieron la conquista.

Que López no era de los más pasivos, y que poseía verbo cálido y persuasivo lo prueba el que fuera elegido en cabildo abierto procurador general de la ciudad de Tunja, oficio concejil de elección popular directa y no mediatizado por la autoridad gubernativa, como sucedía por doquier con las sinecuras ocupadas por las nacientes oligarquías locales instaladas en los respectivos órganos rectores de los concejos. De otro lado el buen entendimiento del de Moratalla queda más que manifiesto en la memoria de agravios que en nombre propio y de su ciudad presentó al adelantado y capitán general de Santa Marta y Nuevo Reino de Granada, Luis Alonso de Lugo, en 17 de noviembre de 1543.

Consta ser Juan López procurador de Tunja, al menos desde 6 de noviembre del expresado año, fecha de cierta probanza por él suscrita (37). El documento evidencia cuán afanado andaba por entonces el inquieto murciano en el servicio público, y las absorbentes gestiones que venía practicando a fin de obtener importantes ventajas para la ciudad cuya representación le había sido confiada.

El movimiento de protesta estalló en Tunja, donde parece que los agravios eran mayores, y cuyo ejemplo no tardó en cundir por el resto del reino. Tan sólo Santa Marta y la costa permanecieron fieles al gobernador. En tanto duró el levantamiento, Tunja, centro de la revuelta, arrebató de hecho la capitalidad de la

(37) AGI, Patronato, Leg. 195, ram. 11: Probanza realizada en Tunja a solicitud de Juan López, procurador de esa ciudad, 1543, 19, fs. [fs . 33r-50v]. 
Nueva Granada a la ciudad de Santa Fe de Bogotá, de igual forma que en Perú sucediera en Cuzco respecto a la Ciudad de los Reyes, la capital oficial, que junto con el litoral permaneció leal a la autoridad virreinal. Sin duda porque en ambos casos al darse superiores densidades de población autóctona en el interior respecto a la periferia, y por tanto ser mayor la dependencia del trabajo del indio, encomenderos y demás pobladores se sentían más perjudicados en sus intereses con la introducción de un cuerpo legislativo favorable al indígena.

Principal instigador del movimiento, sin duda por ser uno de los agraviados más notorios, fue Juan López, quien una vez designado procurador general en concejo abierto, obtuvo asentimiento expreso a tal nombramiento de la desacreditada corporación concejil, desbordada por los acontecimientos. De inmediato López entró en contacto con las restantes ciudades del naciente reino, sumándosele las de Vélez y Tocáima de los Pánchez, donde a su vez los cabildos constituídos delegaron poderes en sendos procuradores de elección popular, y finalmente por la capital, Santa Fe, donde los ediles optaron por plegarse al sentir del vecindario y sumarse a la protesta desde el principio, al tiempo que era autorizada la elección de procurador.

Logrado este objetivo, el de Tunja, facultado por sus restantes colegas, abrió negociaciones con el nuevo adelantado y capitán general Luis Alonso de Lugo, desplazado al efecto desde Santa Marta y Santa $\mathrm{Fe}$, presentándole el ya aludido memorial de agravios (38), fechado en Tunja en 17 de noviembre de 1543 y suscrito por medio centenar de vecinos, entre los cuales el murciano Martín Pujol.

En este documento eran hechos los más duros cargos a los gobernadores Hernán Pérez y Gonzalo Suárez, quienes no tardarían en ser destituídos y residenciados. Ante todo se les acusaba de venir practicando una política de arbitrario alejamiento de los conquistadores y de los colonos con mayor antigüedad y merecimientos, para favorecer sus intereses particularistas y los de sus protegidos, y subsidiariamente - acusación que debía haber sido la angular pero que preocupaba menos a los reclamantes- de atropellos con los indios.

Por todo ello era solicitado del capitán general Luis Alonso de

(38) AGI, Patronato, leg. 195, ramo 9: Petición de Juan López, procurador de Tunja, en nombre de Francisco Salguero, Juan de Pinilla y otros conquistadores de la misma ciudad y provincia, quejándose del mal reparto de la tierra, cedida a quienes no la habian conquistado y demandado nuevo repartimiento. Tunja 11 noviembre 1543, $4 \mathrm{fs},(25 \mathrm{r}-28 \mathrm{r})$. 
Lugo que pasara a la región de Tunja para proceder a una redistribución equitativa de la misma. Una vez Lugo en Tunja, habiéndosele leído por López el cuaderno de quejas en cabildo abierto, y habiendo recibido y estudiado el documento, al siguiente día -18 de noviembre- ante escribano y testigos «...el dicho señor, respondiendo al requerimiento hecho por el dicho Juan López, procurador, dijo que su voluntad de continuo ha sido y es servir a Su Majestad y acertar en todo lo que en su real servicio hiciere, y (...) que luego, con toda brevedad haría el dicho repartimiento, según y como Su Majestad lo manda y conforme a la disposición de la tierra" (39).

\section{Contra las Leyes Nuevas}

Habiendo visto atendidas López y sus compañeros siquiera una parte de sus reivindicaciones, y reforzada su presencia en el cabido de Tunja y en los organismos rectores de los otros concejos, se aprestaron a dar la batalla a las denostadas Leyes Nuevas, por estimarlas altamente lesivas a sus intereses corporativos y económicos.

El momento era propicio dado que en los tres años siguientes (1544-1546) la autoridad gubernativa no dejó de deteriorarse por causa del rechazo generalizado entre los pobladores de las nuevas disposiciones legislativas emanadas de la metrópoli y por la actuación cuestionada de gobernadores como Lope Montalvo de Lugo. Se comprende que el levantamiento de Gonzalo Pizarro en el Perú por motivos hasta cierto punto afines a los que se daban en la Nueva Granada, no dejara de suscitar aquí espectación cuando no simpatías.

El malestar llegó a tal punto y las quejas se dejaron oír en España de manera tan tenaz y reiterada, que el monarca dispuso que el licenciado Miguel Díez de Armendáriz, a la sazón en Cartagena de Indias, donde se hallaba residenciando al adelantado de esa provincia y fundador de la ciudad, Pedro de Heredia, y a sus oficiales, $\tan$ pronto ultimara sus trabajos pasase a hacer lo propio en el Nuevo Reino, de cuyo gobierno además debería hacerse cargo. Entre tanto enviaría un representante en calidad de teniente general, como en efecto lo hizo en noviembre del 46. El nombramiento recayó sobre el navarro Pedro de Orsúa, primo de Armendáriz, y que permanecería en el gobierno año y medio

(39) Cfr. FrIEDE, Documentos..., VII, págs. 123-124. 
antes de su marcha al Perú para participar en la represión del levantamiento pizarrista y fallecer un tiempo después en la célebre y malaventurada expedición por el Amazonas a la búsqueda del Dorado y Omagua, que protagonizase con el tétrico vasco Lope de Aguirre.

Orsúa fue un gobernante prudente, dúctil y voluntarioso, que se esforzó en cortar abusos y que residenció a un elevado número de funcionarios grandes y pequeños, comprometidos con la anterior situación. Impulsor de la colonización, fundó nuevas poblaciones, entre las cuales la ciudad de Pamplona, en recuerdo de su patria, y se afanó en el desarrollo y progreso del territorio, donde dejó excelente recuerdo. "Y en este tiempo - referiría luego Juan López en carta conjunta con los procuradores de Vélez, Tocáima y Santa Fe, dirigida al emperador a finales de 1547 (40)- nos tuvo y nos sustentó en justicia y en toda quietud y sosiego, y en servicio de Dios y de Vuestra Majestad, haciendo el deber en todo, como muy celoso del servicio de Vuestra Majestad y persona enviada por mano del licenciado Miguel Díez, y aunque con todo esto, no era poco deseada su venida [de Díez] a este Reino, por las causas dichas».

Orsúa halló una resistencia tan tenaz a las Leyes Nuevas por parte de las ciudades federadas neogranadinas que, no obstante haber sido ya pregonadas, hubo de suspender su aplicación por dos años en el territorio de su jurisdicción, en tanto los pobladores neogranadinos gestionaban en la corte su parcial derogación o conveniente adaptación, por entender, según escribieron al emperador el cabildo de Santa Fe conjuntamente con Juan López, García Calvete y Sebastián de Pomar, procuradores de Tunja, Vélez y Tocáima, reunidos en la capital, ser «algunas de ellas intolerables" y que supondrian "...nuestra destrucción total si se guardasen y ejecutasen». Por ello, y para escapar al despotismo de los gobernadores (41), reclamaban, a su vez, la creación de una Real Audiencia, creada en efecto en 1549, si bien no entró en pleno funcionamiento hasta catorce años más tarde, en que llegó su primer presidente (42).

Al reactivarse el contencioso de las Leyes Nuevas con la

(40) AGI, Justicia, leg. 1.116-B (Sobre aplicación de las Leyes Nuevas en el N.R. de Granada y protestación de Juan López, procurador general de Tunja 1547). Véase, a su vez: Ibídem, Audiencia de Santa Fe, legs. 60 y 66 (Reivindicaciones de Juan López y de los otros conquistadores de Tunja. 1546-1547).

(41) Aguado, Primera parte / de la / Recopilación... I, pág. 353.

(42) J. B. Ruiz Rivera, Encomienda y mita en Nueva Granada en el siglo XVII. Prólogo de L. Navarro García. Sevilla. 1975, pág. 129. 
llegada de Díez, provisto de instrucciones para hacerlas aplicar, Tunja y su procurador Juan López tomaron de nuevo la iniciativa para resistirlas. Ya en 5 de enero del 47 el murciano, al tiempo que notificaba al licenciado haber hecho su ciudad un llamamiento a las otras del Nuevo Reino para que se reunieran sus representantes en Santa Fe con el fin de acordar la acción conjunta de seguir en relación con las Nuevas Leyes para mejor servicio de la Corona y del bien común, le requería en derecho *...en nombre de esta ciudad y república, que en el entretanto que los dichos se juntaren, Vuestra Merced sobresea la ejecución de las dichas nuevas ordenanzas y de cada una dellas" (43).

Como quiera que el gobernador denegase tal petición alegando haber sido enviado por el monarca a aquel dilatado y convulsionado país precisamente como juez ejecutor y comisario de las Leyes Nuevas, y que por tanto las haría cumplir, todo lo cual fue comunicado a López y al cabildo de Tunja por auto del escribano Alonso Téllez, y habiendo sido desestimado otro requerimiento del murciano, quien entendía que el acuerdo del gobernador "...hablando con el acatamiento debido, es injusto y (...) digno de revocarn, máxime cuando las referidas Leyes ya lo habían sido «...en la mayor parte de las Indias, donde se ha suplicado de ellas» (44), el procurador se remitía en este asunto a la decisión directa del rey, a quien se había acordado acudir para obtener la abolición total o parcial de una normativa reputada como contraria al bien público y a la tranquilidad del país. Dicho esto, López responsabilizaba al gobernador del caos que pudiera suscitarse de insistir en su empeño, si es que con tal actitud no daba lugar a la destrucción de aquellas provincias.

El ejemplo de Tunja cundió por doquier. Santa Fe, Vélez y Tocáima se sumaron a la protesta y las cuatro ciudades elevaron un requerimiento conjunto al gobernador general por vía de justicia, apremiando ahora no la suspensión sino la revocación de la nueva normativa en territorio neogranadino. Todo en vano, dada la irreductibilidad de Díez. A su vez fueron practicadas gestiones directas en la Corte y el Consejo de Indias por los enviados Pedro de Colmenares y Alonso Téllez, que así como una extensa misiva justificativa fechada en Tunja en 7 de di-

(43) AGI, Patronato, leg. 195, ramo 15: Testimonio de suplicación que se hizo en el $N^{o} R$ no, de / Granada sobre la modificación de las leyes impueslas / por el Lcdo. Miguel Diez de Almendáriz. Juez de residencia y gobernador de aquel Reyno. (5 enero) $1547,28 \mathrm{fs}$. [179r-230v].

(44) 2\% requerimiento de López a Díez de Armendáriz, s.f., cfr. Friede, Documentos..., IX, Pags. 101-102. 
ciembre de 1574, tampoco dieron los frutos apetecidos. A las ciudades neogranadinas conjuradas no parecía quedarles otra salida para sacar adelante sus pretensiones que el recurso a la fuerza.

Reticencias a intervenir en la represión del levantamiento pizarrista del Perú

La protesta contra las Leyes Nuevas, especialmente tenaz en el espacio neogranadino, aquí no podía dejar de conectarse a la guerra civil peruana, de compleja etiología pero suscitada hasta cierto punto por igual motivo. Tal circunstancia no escapó a los dirigentes de ambos movimientos, conscientes de que la suerte del uno dependería en considerable medida de la seguida por el otro. Sobre todo en el caso de la Nueva Granada, cuyo programa reivindicativo resultaba ser bastante más modesto que el peruano, por concretarse a la consecución de objetivos más económicos que propiamente políticos.

Ello no fue óbice para que López y sus asociados, quienes no parece que en ningún momento se plantearan lanzarse a la abierta rebelión, y menos sumarse a la de Gonzalo Pizarro en el Perú, aireasen el fantasma de una posible extensión de la guerra civil a la Nueva Granada, caso de verse burlados en sus pretensiones. Por lo mismo, practicaron una política obstruccionista a la cooperación neogranadina brindada a las autoridades realistas del Perú por los gobernadores Orsúa y Díez para la represión del movimiento insurreccional. Sobre todo en la región minera de Tunja, cuyos condicionamientos estructurales resultaban ser bastantes similares a los del alto Perú, plataforma principal de la insurrección.

Tal retraimiento se puso de manifiesto en todo momento, pero en particular cuando en 1546 y primera mitad del siguiente año fueron reunidas algunas tropas que con Orsúa marcharon a reforzar el ejército del presidente de la Audiencia, don Pedro de la Gasca, enviado desde España como virrey en funciones y pacificador, y luego cuando en el invierno del 47 el gobernador Díez hizo nuevos aprestos para participar en una contraofensiva general realista desde todos los frentes, frustrada en parte, en lo que a la Nueva Granada se refiere, por la escasa concurrencia de los pobladores, no obstante ser gratificados con un uavivamienton o ayuda de costa con cargo a las arcas reales, y por la masiva deserción de los enrrolados, quienes por causas diversas 
no pasaron más allá de Tocáima de los Panches, no sin viva irritación de Díez, que con escaso éxito les conminó a regresar a sus puestos - Tunja, 6 noviembre 1547 (45)- bajo amenaza de penas fluctuantes entre la capital (por traición) y confiscación de bienes.

A juzgar por los negros presagios que parecían seguirse para la causa realista del aniquilamiento de las vanguardias del nuevo ejército real, nadie podía predecir que tan sólo meses más tarde -abril de 1548 - la generalizada insurrección iba a ser conculcada con puño de hierro por el abogado La Gasca. Con la pacificación llegó la plena vigencia de las Leyes Nuevas y también el momento de pasar cuentas a quienes habian mostrado desafección, doblez o frialdad en los difíciles tiempos pasados. Todos ellos fueron privados de sus encomiendas, entregadas ahora a quienes habian dado pruebas de manifiesta lealtad.

Las correspondientes causas fueron iniciadas ya por Díez de Armendáriz en el 47, remontándose algunas al bienio 1545-1546. Centenares de personas fueron procesadas, $y$ no pocas sufrieron penas diversas con confiscación de bienes en todo o en parte, como fue el caso del murciano Martín Pujol. Aún quienes pudieron probar su inocencia, no dejaron de ser investigados en su conducta pasada, en el origen de sus patrimonios o «sobre la propiedad de los indios", investigaciones que solían ir seguidas de confiscaciones, o de un segundo procesamiento criminal, como aconteció al capitán Suárez (46).

López no fue la excepción. Consta un inicial «Proceso de despojo de Juan López, vecino de Tunja» (47), del que no debió salir mal parado, o en caso contrario debió rehacer su patrimonio con relativa rapidez, dado que después del 48 López figura en el número de los encomenderos como titular de Sachica. Su inclusión entre aquéllos que siendo conquistadores de primera hora lograron retener sus encomiendas $u$ obtener otras nuevas al término de las contiendas civiles de la década de 1540, es signo inequívoco de que en el momento decisivo, estuvo del lado de los vencedores.

En efecto el murciano, procurador general de Tunja y entre los más destacados adalides, si no el principal, del movimiento en

(45) CAr. Friede, Documentos..., LX, págs. 144-184.

(46) M. García Samudio, Crónica del muy magnífico Capitán don Gonzalo Suárez Rendón. Bogotá. 1939.

(47) "Relación de escrituras en poder del escribano Alonso Téllez, 1547", cfr. FRIEDE, Documentos..., IX, pág. 93. 
pro de la redistribución de tierras entre quienes hicieran la conquista, contra el gobierno despótico de dignatarios todopoderosos y en favor de los intereses corporativos de los encomenderos, pasará discretamente a un segundo plano al conectar la protesta neogranadina con la insurrección peruana, para borrarse después su nombre de los listados de gentes de dudosa lealtad o comprometidos con la facción. Quien había logrado el raro prodigio de ser líder populista y al propio tiempo mantener irreprochables relaciones personales con la autoridad cuestionada, no podía caer en el craso error de confundir la más porfiada defensa de sus intereses personales y los de sus representados, simbolizada en el emblemático rechazo de las Leyes Nuevas, con la rebelión contra España.

Tal era el sutil y ambiguo lindero entre la lealtad y la traición que, por el contrario, si fue cruzado por otros muchos conjurados. En ello radica evidentemente la diferencia entre Juan López, procurador de Tunja y alma de la protesta neogranadina, y Francisco de Carvajal, procurador de Cuzco e inductor principal con Gonzalo Pizarro de la insurrección peruana.

\section{LOS ÚlTIMOS AÑOS DE LÓPEZ}

Los inconvenientes seguidos de la presencia en Indias de tantos hombres sin familia, más afanosos de correr aventuras, de llevar una vida suelta, y en ocasiones disoluta, y de buscar un enriquecimiento rápido para regresar a España, que de sentar vecindad y poblar el país, determinó a la Corona, alertada por obispos y oficiales reales, a dictar medidas para obtener su sedentarización. De un lado obligando a los casados a llamar a traer personalmente a sus mujeres, y de otro propiciando el matrimonio de los solteros.

En tal dirección, y en lo que se refiere al Nuevo Reino de Granada, apuntaba una Real cédula dada en Valladolid en 17 de octubre de 1544 (48), a la que siguió otra en igual sentido fechada en Madrid en 29 de noviembre del 46. Las dificultades del momento, a que ya ha sido hecha referencia, impidió su cumplimiento en ambos casos. El restablecimiento pleno de la normalidad a finales de 1548, una vez liquidada la sedición pizarrista en Perú, posibilitó la aplicación de ambas Reales órdenes a partir de febrero del siguiente año. Esta vez no quedaba a López otra

(48) Cfr. Friede, Documentos..., VII, págs. 249-250. 
salida que la de ir a por la familia, al no poder alegar razones de fuerza mayor o servicio público, por haber cesado hacia más de un año como procurador general de la ciudad de Tunja.

Circunstancias diversas demoraron su marcha hasta $1552 \mathrm{y}$, al término de unos meses en España, regresó a Indias a mediados del 54, dentro de los dos años previstos por la ley para realizar la doble y arriesgada singladura de ida y vuelta. La llegada del encomendero López a Moratalla, a su pueblo de origen, demorada por tan largo tiempo, resultó ser todo un acontecimiento. Tanto fue así que, al emprender el regreso, aparte de su mujer Elvira Sánchez y de su hija, de un criado vecino de la misma localidad, Lope Sánchez, y de otros dos de fuera, Luis Calderón, natural de Tordesillas, y la sevillana Beatriz Nuñez, ésta sirvienta de la mujer e hija de López, le acompañaron otras catorce personas. Ginés Sánchez de Josa, convecino y acaso pariente del indiano, rico hacendado que llevaba consigo a su mujer María Martínez y seis hijos, y naturalmente todo cuanto poseía por haber liquidado sus bienes y pertenencias en su localidad natal al objeto de invertir en Tunja adquiriendo una buena propiedad rústica; llevaba contratado como "labrador criado» a Francisco Sánchez, vecino de Valdecasa y como sirviente doméstico a Hernán Quixada, vecino de la villa de Aznaga. Los restantes emigrados lugareños con destino a tierras neogranadinas -Pero García de Zárate y su mujer Elvira Rodríguez, Ginés Sánchez García y Juan García de Ranera, todos de Moratalla- eran gente de menos posibilidades. Todos, de alguna forma, marchaban a la sombra de López y Sánchez (49).

Todos ellos se embarcaron en la armada de Juan de Junco, el antiguo lugarteniente de Jiménez de Quesada, que había venido a España a suscribir acuerdos con el Consejo de Indias y llevar consigo pobladores. Habiendo pasado los controles de la Casa de la Contratación según estaba preceptuado, cada cual al tomar pasaje se acomodó como pudo, según consta en los asientos correspondientes. "Juan López, vecino de Moratalla. Estante en Tunja, del Nueuo Reyno de Granada. Hijo de Gonzalo Sánchez y de Elbira Rodríguez. Se despachó para el Nueuo Reyno de Granada con Elbira Sánchez, su muger, e una hija, en la nao de Alonso de Campos" (50). Con los López embarcaron las personas

(49) VILAR, El indiano..., págs. 95-103; VILAR, Los murcianos y América..., 239. 241. Sobre el viaje de López a España. Véase, a su vez, AGI, Audiencia de Santa, leg. 533.

(50) AGI, Contratación, leg. 5.537, t. 1, f. 6v (asiento $n^{Q}$ LXXV). 
de su servicio y el matrimonio García de Zárate (51). No así la familia Sánchez de Josa, que lo hizo «...en la nao de Meléndez" (52).

La existencia de López y de su familia, después de 1554, discurrió entre Tunja, donde tenía casa y vecindad, y su encomienda de Sachica. El murciano se las había arreglado para conservar su patrimonio al término de las revueltas neogranadinas, acaso por el «modus vivendis a que llegase con el gobernador Díez de Armendáriz durante los pasados sucesos. No se explicaría de otro modo el benigno trato dispensado al que fuera conductor y líder de las ciudades sumadas a la protesta. Tanto más por cuanto el murciano no pasaba por ser precisamente encomendero blando, de lo que da fe el proceso seguido "contra Ramiqui, cacique de Tunja», y ya procurador del territorio, por haberse identificado plenamente con los otros encomenderos frente a las poblaciones autóctonas, como consta claramente en cierto «...requerimiento del procurador de Tunja para [que] se castigue a los indios".

La encomienda de Sachica, en el camino de Tunja a Santa Fe, era la base del patrimonio de López. Una de las más extensas y pobladas de la región -dos millares de indios hacia 1560-. Entre ella y su mansión familiar en Tunja, donde retuvo siempre una parte de su ascendiente e influjo, discurrió la vida del murciano, cuyos negocios y quehaceres sobrepasaron ampliamente el estrecho círculo local y el de la encomienda y explotación agraria que tenía a su cargo. A diferencia de Jiménez de Quesada, que malbarató su fortuna en la búsqueda del Dorado y otras empresas fantásticas, muriendo cargado de deudas (53), su antiguo colaborador Juan López, con rentas más modestas pero con los pies en el suelo, supo administrarse mejor y multiplicar su patrimonio, dando la medida de lo que puede conceptuarse como encomendero empresario.

Rodeado de familiares y amigos, y de la consideración social debida a su rango y fortuna, debió visitarle la muerte entrada la década de 1570. Un tiempo antes falleció su paisano, amigo y compatricio Martín Pujol, en Santa Fe de Bogotá, donde tenía vecindad, dado que en 20 de enero de 1564 su hija Inés, y el marido de esta Ginés Rodríguez, vecinos de la villa de Moratalla,

(51) Ibidem, f. 7 (asiento $n^{\mathrm{Q}}$ LXXXVI).

(52) Ibídem, f. $11 \mathrm{v}$ (asiento no LXXXIX).

(53) RUIz. RIVERA, "De conquistador a colonizador: perfil antiheróico de Jiménez de Quesada", Congreso de Historia del Descubrimiento, II págs. 579 ss. 
daban poder a su sobrino Hernán Ruiz Pujol para cobrar la herencia (54).

No parece que la mujer e hija de López pudieran retener al encomienda de Sachica, no obstante ser numerosas las excepciones constatables a la prohibición introducida por las Leyes Nuevas de transferir hereditariamente la titularidad de encomiendas. Si acaso, lo logró solamente doña Elvira Sánchez, la viuda del encomendero. Lo cierto es que en 1597 ya había salido de la farnilia, dado que en ese año son mencionados (55) don Francisco y doña Magdalena de Velasco como encomenderos de Sachica con 99 indios útiles encomendados sobre un censo evaluable en más de un millar.

(54) AHP, Protocolo $n^{2} 8604$, f. $113 r$ r.

(55) RUIz RIVERA, Encomienda y mita..., págs. 45-95; RuIz RIVERA, fuentes para la demografía histórica de la Nueva Granada. Sevilla. 1972, págs. 38-136. Véase también J. MoJICA SILVA, Relación de visitas coloniales. Pueblos, repartimientos y parcialidades de la provincia de Tunja de los partidos de la Palma, Muzo, Vélez y Pamplona. Tunja. 1946; V. CORTES, "Tunja y sus vecinos", Revista de Indias, 99-100 (1965), págs. 155-207; G. CoLMENARES, La provincia de Tunja en el Nuevo Reino de Granada Ensayo de Historia Social (1539-1800). Bogotá. 1970. Existe, además, una extensa bibliografía sobre el caso singular de Tunja como foco renacentista de primera magnitud en la América meridional, en particular en cuanto se refiere a la arquitectura civil, pero también a otras dimensiones urbanísticas y artísticas (S. Sebastián López, E. Marco Dorta, C. Arbeláez, M. J. Buschiazzo, G. Guarda, F. de Solano, C. Martínez, A. Corradine, H. Molano, etc.) que aportan aportaciones de interés sobre el contexto histórico-geográfico de la impresionante urbe colombiana. 